\title{
Correction to: Structuring First-Year Retention at a Regional Public Institution: Validating and Refining the Structure of Bowman's SEM Analysis
}

\author{
Daniel A. Collier ${ }^{1}$ (D) Dan Fitzpatrick ${ }^{2}$ (D) . Chelsea Brehm ${ }^{3}$ (D) Keith Hearit $^{4}$. \\ Andrea Beach ${ }^{3}$
}

Published online: 29 November 2020

(c) Springer Nature B.V. 2020

\section{Correction to: Research in Higher Education (2020) 61:917-942 https://doi.org/10.1007/s11162-020-09612-w}

The author would like to correct the errors in the publication of the original article. The corrected details are given below.

(a) The co-author "Andrea Beach" affiliation should be changed from "W.E. Upjohn Institute for Employment Research, Kalamazoo, MI, USA" to "Center for Research on Instructional Change in Postsecondary Education (CRICPE), Western Michigan University, Kalamazoo, MI, USA".

(b) Page 917: 5th line, the word "ussing" should be change to "using".

(c) Page 918: 8th line, the word "V2019ia" should be change to "via".

Publisher's Note Springer Nature remains neutral with regard to jurisdictional claims in published maps and institutional affiliations.

The original article can be found online at https://doi.org/10.1007/s11162-020-09612-w.

Daniel A. Collier

Collier@upjohn.org

1 W.E. Upjohn Institute for Employment Research, Kalamazoo, MI, USA

2 LSA Opportunity Hub, University of Michigan, Ann Arbor, MI, USA

3 Center for Research On Instructional Change in Postsecondary Education (CRICPE), Western Michigan University, Kalamazoo, MI, USA

4 School of Communication, Western Michigan University, Kalamazoo, MI, USA 